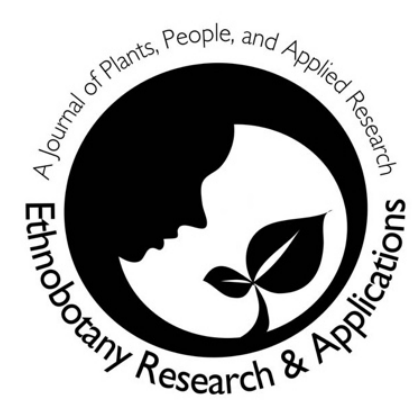

\title{
Traditional knowledge and economic
} significance of Berberis lycium Royle in the District Dir Lower, Pakistan

\author{
Latif Ahmad, Farid Ullah, Andrew J. Semotiuk, Wajid \\ Rashid, Imran Khan, Hammad Ahmad Jan, Rainer W. \\ Bussmann and Imran Ahmad
}

\section{Research}

\begin{abstract}
Background: Berberis lycium Royle is a well-known medicinal plant, belonging to the family Berberidaceae, and is widely distributed in Lower Dir, Pakistan. Parts of $B$. lycium like rhizomes and berries are used by the local people as medicine and food. This research work focused on two major aspects regarding $B$. lycium. Firstly, to determine the various traditional and medicinal uses of $B$. lycium. Secondly, to document its monetary value at local markets in the study area.
\end{abstract}

Methods: Semi-structured and open-ended ethnobotanical interviews, local market inquiries, field observation, and group discussions were conducted from May 2018 to October 2019 to understand ethno-botanical knowledge of $B$. lycium.

Results: In the current study, a total of 61 local people from Dir Lower were interviewed. According to the result of our study, $37 \%$ of informants used the $B$. Iycium for the treatment of diabetes mellitus, followed by infection (12.5\%) and bone repair (10\%). In terms of economic value, the fruits and rhizomes of $B$. lycium are also important. Locally the rhizome was sold for prices ranging between \$3 and \$6 USD per kilogram.

Conclusion: This study concludes that local people of Dir Lower have significant medicinal as well as economic information of $B$. lycium. Because of its high medicinal and market value, it is a warning sign that the plant is highly threatened due to overexploitation. Given this, we suggest to the local and district forestry department, governmental organizations, and non-governmental organizations to encourage, motivate, and also create awareness among the local people to conserve the species for future generations.

Keywords: Ethnomedicine; Market value; Traditional knowledge; Berberis lycium; Dir Lower

\section{Correspondence}

Latif Ahmad ${ }^{\text {1* }}$, Farid Ullah ${ }^{1}$, Andrew J. Semotiuk ${ }^{2}$, Wajid Rashid ${ }^{3}$, Imran Khan', Hammad Ahmad $\mathrm{Jan}^{4^{\star}}$, Rainer W. Bussmann ${ }^{5}$, Imran Ahmad

${ }^{1}$ Department of Botany, Shaheed Benazir Bhutto University, Upper Dir, Pakistan

${ }^{2}$ Department of Botany and Plant Sciences, University of California, Riverside, California, 92507 U.S.A

${ }^{3}$ School of Environment, Beijing Normal University, Beijing, China

${ }^{4}$ Department of Botany, University of Buner, Swari, Pakistan

${ }^{5}$ Department of Ethnobotany, Institute of Botany, Ilia State University, Tbilisi, Georgia

“Corresponding Author: hajmughul@yahoo.com; latifahmad1989@sbbu.edu.pk

Ethnobotany Research \& Applications 20:30 (2020) 


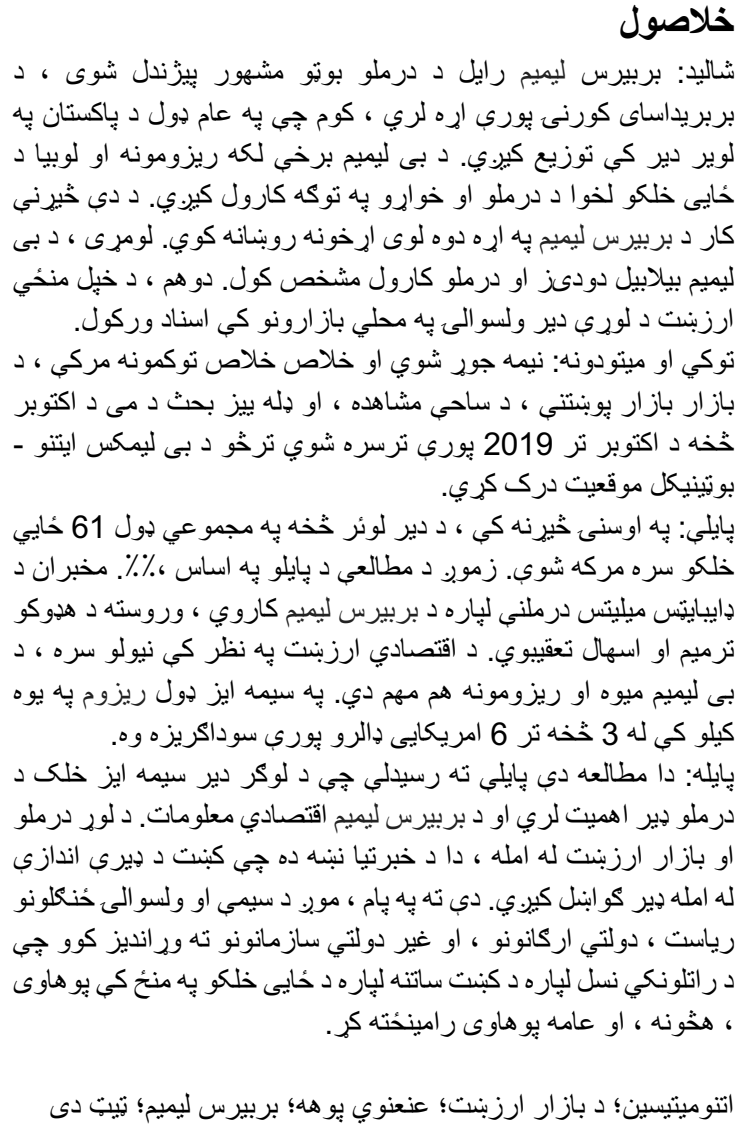

\section{Background}

For thousands of years, herbal medicines have significantly contributed to human health and life protection. Throughout history, mankind has depended on plant resources to fulfill their basic needs such as medicine, food, shelter, clothing, and transportation (Ahmad et al. 2006). Especially in rural areas, and in particular, in many tropical countries, the use of plants provides a fundamental source of drugs, and a portion of the population still depends upon them (Shaheen et al. 2019). Traditionally used plants, animals, and fungi with useful secondary metabolites are hopeful agents for modern drug discovery as they play a vital role in herbal medicine (Newman and Cragg, 2007). The WHO reports that about $25 \%$ of modern medications have been extracted from botanical resources (Rates, 2001). The use of natural drugs as medication still presents a very crucial role in medical care, especially for people of growing nations (Kloucek et al. 2005). Nowadays, medicinal plants play an important role in the lifestyle of traditional people and numerous regionally produced ethnomedicines are used as household treatments for a wide range of human health issues (Qureshi and Ghufran, 2005). Numerous investigations have been conducted to obtain modern drugs from botanical materials (Rashid and Arshad, 2002; Bhatti et al. 1998). About $12.5 \%$ of the 422,000 plant species documented worldwide are reported to have medicinal value. Up to $60 \%$ of the drugs prescribed in Eastern Europe consist of unmodified or slightly altered higher plant products (Abbasi et al. 2011).

Globally, the trade of botanical resources extends mainly in the form of patent medicines, plant extracts, rhizome, decoction pieces, and products of health care (Zhu et al. 2016). The worldwide market of traditional and ethnomedicine based on herbs and their relevant products have seen a considerable increase in the last three decades. Around the globe, demand and trade of botanical products are rapidly increasing day by day (Baydoun et al. 2015). For example, in 2014, the ethnomedicine industrial output value in China reached 730.2 billion yuan; in the US, the 2008 out-of-pocket expenses for natural products were $\$ 14.8$ billion. While in South Korea, the annual expenditure on traditional medicine was $\$ 4.4$ billion in 2004 and increased to $\$ 7.4$ billion in 2009 (Zhu et al. 2016). Similarly, Pakistan also occupies a key position in the international botanical products trade. In the herbal products import, Pakistan has a 9th position (11,350 tons), on another note, the export rank is $10^{\text {th }}$ (8100 tons) (Khan and Rauf, 2014).

Pakistan has unique biodiversity due to its different climatic zones, including a wide range of wild plant species. The country has a rich flora in which 2,000 plant species are used at one time or another, in one culture or another, for medicinal purposes, but of these 2,000 Pakistani species, about 400-600 are documented and studied for medicinal purposes (Abbasi et al. 2011). According to one report in Pakistan, a total of 1,572 plant genera and about 5,521 species of angiosperms are identified. Among these, nearly 600 plants are known to be important medicinally. Of these plant species, about 400 species of plants are believed to be endemic to Pakistan (Ali, 2008). An explorative survey conducted by the Pakistan Forest Institute determined that 75 of crude ethnomedicine are widely exported while more than 200 are traded locally in Pakistan (Hamayun et al. 2005). In rural areas, ethnomedicine still plays a significant role and is still used as the primary healthcare system. According to an estimate, about $80 \%$ of people of remote regions of Pakistan are still dependent on medicinal plants (Qureshi and Ghufran, 2005; Jan et al. 2017).

B. Iycium Royal is a well-known medicinal plant belonging to the family Berberidaceae. Barberry is the English name of Berberis lycium, it is called Ishkeen in Urdu, and locally it is known as Zyar largay/Kwaray in Pashto. Berberis is a large genus with nearly 400 species, widely distributed in 
America, Asia, and the Mediterranean region. In Pakistan, there are about 20 species; most of them distributed in the northern regions of Gilgit, Dir, Hazara, Murree, Kashmir. Hazara, Jhelum Valley, Gilgit, Swat, and Chitral.

$B$. Iycium is a spiny shrub, sub-erect or erect, about $6 \mathrm{ft}$ tall. Leaves simple, oblanceolate to oblong and sub-sessile. Flower pale yellow and pedicellate. The edible berries of B. lycium 7-8 mm long, 5-6 mm wide, oval-shaped, with acidic taste (Flora of Pakistan, 1989). Several Berberis species are wellknown as alternate hosts for rust fungi, especially of wheat and some other cereals. The present study had three aims: (i) To determine the traditional and medicinal uses of $B$. lycium Royle in villages of Dir Lower, (ii) To investigate and document the ethnobotanical uses pertaining to different parts of $B$. lycium in Lower Dir regions, and (iii) To identify the local market value of $B$. lycium in Lower Dir.

\section{Materials and methods \\ Ethnographic and physical description of the study area}

The current research work was carried out in the district of Dir Lower, Khyber Pakhtunkhwa, Pakistan. Dir Lower shares an international boundary with Afghanistan in the west, the district of Bajuar in the south, the district of Swat on its east, and Dir Upper on its north-west and north respectively. It has an area of 1583 square kilometers. Lower Dir lies in the lesser Hindukush range between $35^{\circ}-10^{\prime}$ to $35^{\circ}-16^{\prime} \mathrm{N}$ Latitude and $71^{\circ}-50^{\prime}$ to $71^{\circ}-83 \mathrm{E}$ Longitudes (Ahmad et al. 2015; Khan et al. 2010). The climate of Lower Dir is temperate and receives its highest rainfall in March and its lowest in July, October, and November. The average elevation of Dir Lower ranges from $700 \mathrm{~m}$ to $2,800 \mathrm{~m}$ above sea level and the climate largely depends on altitude (Figure 1).

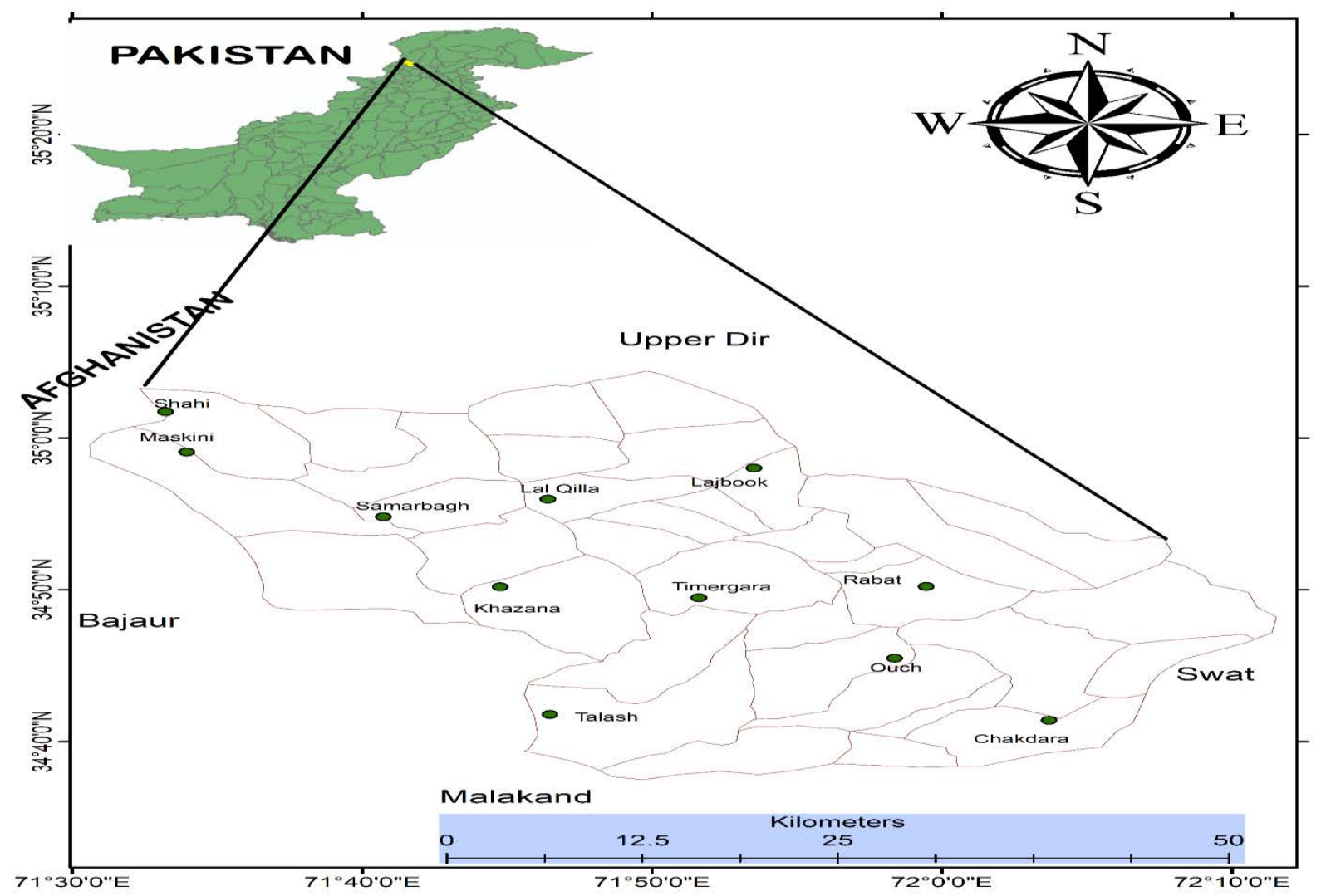

Figure 1. Map of the study area (Dir Lower)

\section{Field survey}

Regular plant collection trips, field observation, and ethnobotanical surveys were arranged from March 2018 to October 2019 in 30 villages of the district Dir Lower for the purpose to collect and document traditional knowledge from the native peoples regarding $B$. lycium. Before starting the semistructured and open-ended interview, we informed local participants that it was a student academic project and investigation was only for our research purposes, not for any commercial or other benefits, and obtained their consent for the study.

\section{Data collection and ethnobotanical interviews}

This ethnobotanical survey was conducted in 30 villages. We contacted 61 respondents for interviews including native elder people, traditional practitioners, Homeopaths, Hakeems (local 
practitioners), and market vendors who had sufficient knowledge of $B$. lycium. All the ethnobotanical interviews, inquires, and group discussion with local people were conducted in the local language Pashto. Taking guidance from Martin (1995) and Cotton (1996), in ethnobotanical interviews and group discussions with local respondents, we asked questions regarding the vernacular name of the plant, morphological parts of the plants used, medicinal use, flowering and fruiting period the modes of administration and preparation, complete recipes and drug preparation

\section{Plant collection, identification, and deposition}

$B$. lycium specimens were collected from 30 different sites in the district Lower Dir during regular plant collections trips arranged according to the fruiting or flowering season. Fruiting or flowering shoots of $B$. lycium were collected from different sites and we recorded detailed information in our field notebook. After confirming plant identity with informants, the plants were collected and photographed. The collected plants were pressed and dried in the newspapers and blotting papers. The collected plants were later brought to the herbarium in the Department of Botany, Shaheed Benazir Bhutto University Sheringal, and Pakistan.

\section{Results and Discussion}

\section{Demographic distribution of the participants}

During ethnobotanical surveys, a total of 61 considerable respondents who used $B$. lycium in the context of local traditional practices and knowledge were interviewed. Among the 61 informants, 45 were men and 16 were women (Table 1). After the inquiry, the data were divided on the basis of people's ages into four groups. Of these, the majority of respondents belonged to the age range $51-70$ years (34\% informants) followed by $30-50$ age $(31 \%)$, 71 80 age $(23 \%)$, and $81-90(12 \%)$ years of range (Figure 2). The lesser number of female respondents was due to cultural norms in the study area. Women are reluctant to talk with people outside of their family (Ahmad et al. 2015). Furthermore, female informants were mainly involved in preparation of herbal recipes in the home. During ethnobotanical interviews, it was observed that mostly male informants were involved in B. lycium collection, market trading, and herbal formulation.

\section{Part of the plant used and treatment of human health issues}

During the ethnobotanical interviews, it was confirmed that only rhizome and fruit of $B$. lycium were used for the treatment of different kinds of human health problems (Figure 3). About $60 \%$ of informants confirmed used the rhizome for different human health issues. Forty percent of the local people used the berries of $B$. lycium for the treatment of diabetes mellitus and also as an antipyretic (Table 2).

The rhizomes of $B$. Iycium contain the alkaloid berberine which has significant antibacterial activities. It was found that inhibitory activity was shown by the components present in the root extracts of $B$. lycium and not by the solvents used for extraction (Irshad et al. 2013). Anamaya and Hasanuzaman (2006) report that the berries of $B$. lycium are a purgative and cooling, and also used for the release of intestinal colic and pharyngitis. Fruit decoction of $B$. lycium is also used in typhoid fever.

Table 1. Number of informants in different study sites of Dir Lower in ethnobotanical survey

\begin{tabular}{|c|c|c|c|c|c|c|c|c|}
\hline Study area & Adenzi & Timergara & Khal & LalQilla & Munda & Samarbagh & Balambat & TOTAL \\
\hline Total Informants & 5 & 9 & 9 & 9 & 11 & 11 & 7 & 61 \\
\hline \multicolumn{9}{|l|}{ Male Respondents } \\
\hline Local elders & 2 & 4 & 5 & 4 & 3 & 4 & 4 & 26 \\
\hline Hakeem & 1 & 2 & 1 & 2 & 1 & 1 & 1 & 09 \\
\hline Market vendor & 1 & 2 & 2 & 2 & 1 & 1 & 1 & 10 \\
\hline $\begin{array}{l}\text { Female } \\
\text { Respondents }\end{array}$ & & & & & & & & \\
\hline Local elders & 1 & 1 & 1 & 1 & 6 & 5 & 1 & 16 \\
\hline \multicolumn{9}{|l|}{ Education Level } \\
\hline Illiterate & 3 & 2 & 3 & 3 & 2 & 5 & 2 & 20 \\
\hline Elementary school & 2 & 1 & 3 & 1 & 2 & 2 & 2 & 13 \\
\hline Secondary school & 1 & 1 & 2 & 1 & 1 & 2 & 1 & 09 \\
\hline High school & 1 & 2 & 0 & 2 & 2 & 3 & 1 & 11 \\
\hline University & 1 & 0 & 2 & 1 & 0 & 1 & 3 & 08 \\
\hline
\end{tabular}




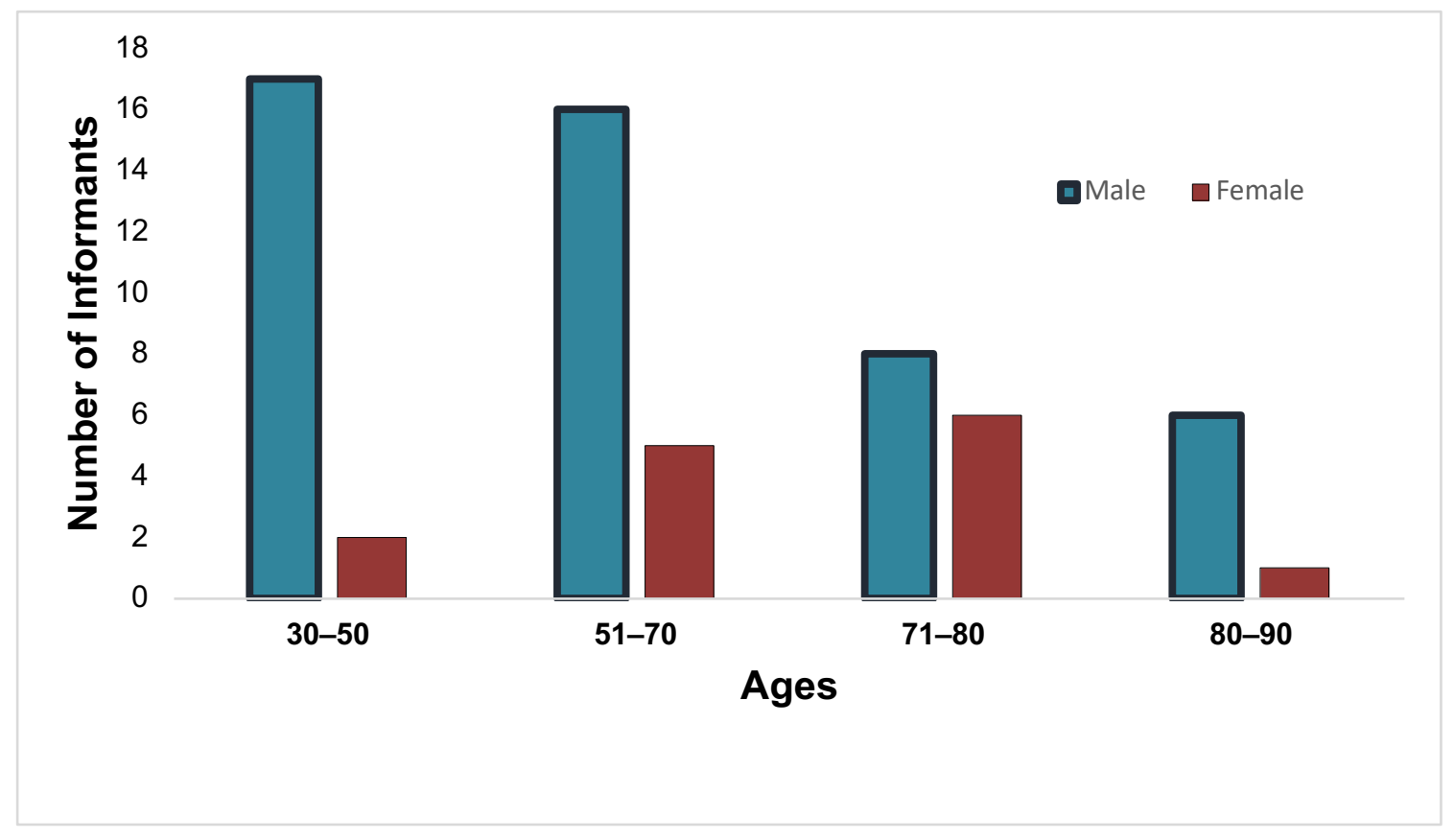

Figure 2. Age distribution of the respondents interviewed

\section{Part of the plant used and treatment of human} health issues

During the ethnobotanical interviews, it was confirmed that only rhizome and fruit of $B$. lycium were used for the treatment of different kinds of human health problems (Figure 3). About $60 \%$ of informants confirmed used the rhizome for different human health issues. Forty percent of the local people used the berries of $B$. lycium for the treatment of diabetes mellitus and also as an antipyretic (Table 2).
The rhizomes of $B$. lycium contain the alkaloid berberine which has significant antibacterial activities. It was found that inhibitory activity was shown by the components present in the root extracts of $B$. lycium and not by the solvents used for extraction (Irshad et al. 2013). Anamaya and Hasanuzaman (2006) report that the berries of $B$. lycium are a purgative and cooling, and also used for the release of intestinal colic and pharyngitis. Fruit decoction of $B$. lycium is also used in typhoid fever.

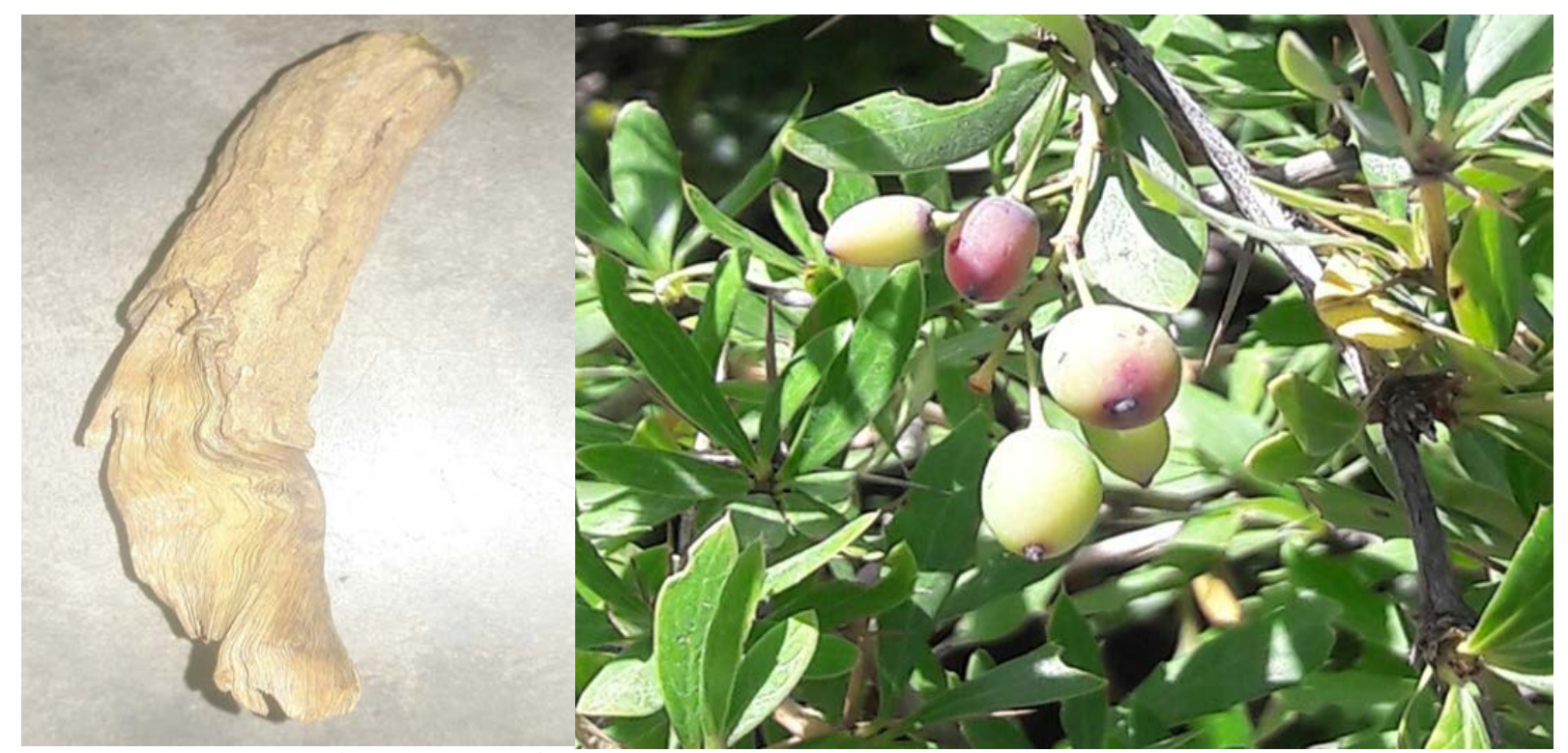

Figure 3. Rhizome and fruiting shoot of Berberis lycium Royle 
Table 2. Identified medicinal and market value of Berberis lycium in Lower Dir.

\begin{tabular}{|c|c|c|c|c|c|}
\hline Study site & Part Used & $\begin{array}{l}\text { Mode of } \\
\text { Preparation }\end{array}$ & $\begin{array}{l}\text { Mode of } \\
\text { Administration }\end{array}$ & Medicinal uses & $\begin{array}{l}\text { Market price } \\
\text { (US } \$ / \mathrm{Kg} \text { ) }\end{array}$ \\
\hline \multicolumn{6}{|l|}{ Sumer Bagh Tehsil } \\
\hline Kambat & $\begin{array}{l}\text { Rhizome } \\
\text { Fruit }\end{array}$ & $\begin{array}{l}\text { Decoction } \\
\text { Direct }\end{array}$ & Oral & $\begin{array}{l}\text { Diabetes mellitus, repair of bone, chest infection } \\
\text { Diabetes mellitus }\end{array}$ & 2.50 \\
\hline Shahi & Rhizome & Poultice & Oral & Cancer, clean of blood, infection of eye & 3.00 \\
\hline & Fruit & \multicolumn{4}{|c|}{ Timergara Tehsil } \\
\hline mimergard lensil & & & & Ulcer, heart burn, and also for serum glutamic & \\
\hline Timergara city & $\begin{array}{l}\text { Rhizome } \\
\text { Fruit }\end{array}$ & $\begin{array}{l}\text { Powder } \\
\text { Direct }\end{array}$ & Externally & $\begin{array}{l}\text { pyruvic transaminase (SGPT) } \\
\text { Diabetes mellitus }\end{array}$ & 5.00 \\
\hline Khongay & $\begin{array}{l}\text { Rhizome } \\
\text { Fruit }\end{array}$ & $\begin{array}{l}\text { Decoction } \\
\text { Direct }\end{array}$ & Oral & $\begin{array}{l}\text { Skin and stomach complaints } \\
\text { Diabetes mellitus }\end{array}$ & 4.50 \\
\hline Tarry & $\begin{array}{l}\text { Rhizome } \\
\text { Fruit }\end{array}$ & $\begin{array}{l}\text { Decoction } \\
\text { Direct }\end{array}$ & Oral & $\begin{array}{l}\text { Diabetes mellitus mouth and throat infection } \\
\text { Diabetes mellitus }\end{array}$ & 3.50 \\
\hline \multicolumn{6}{|l|}{ Lalqilla Tehsil } \\
\hline \multicolumn{6}{|l|}{ Munda Tehsil } \\
\hline Main-Kelly & $\begin{array}{l}\text { Rhizome } \\
\text { Fruit }\end{array}$ & $\begin{array}{l}\text { Decoction } \\
\text { Direct }\end{array}$ & Oral & $\begin{array}{l}\text { Treatment of mouth, and SGPT } \\
\text { Diabetes mellitus }\end{array}$ & 3.00 \\
\hline Band & Fruit & Direct & & Diabetes mellitus & \\
\hline \multicolumn{5}{|r|}{ 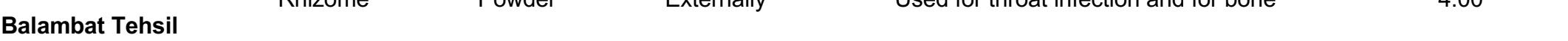 } & 4.00 \\
\hline $\begin{array}{l}\text { Khaima } \\
\text { Kain }\end{array}$ & $\begin{array}{l}\text { Fruits } \\
\text { Rhizome }\end{array}$ & $\begin{array}{l}\text { Direct } \\
\text { Powder }\end{array}$ & externally & $\begin{array}{l}\text { Diabetes mellitus } \\
\text { Diarrhea infection of eve }\end{array}$ & 5.50 \\
\hline Kandaro & Fruit & Direct & & Diabetes mellitus & \\
\hline \multicolumn{6}{|l|}{ Adenzai Tehsil } \\
\hline Talash & $\begin{array}{l}\text { Rhizome } \\
\text { Fruits }\end{array}$ & $\begin{array}{l}\text { Powder } \\
\text { Direct }\end{array}$ & Externally & $\begin{array}{l}\text { Used for chest infection, and SGPT } \\
\text { Diabetes mellitus }\end{array}$ & 6.00 \\
\hline Chakdara & $\begin{array}{l}\text { Rhizome } \\
\text { Fruits }\end{array}$ & $\begin{array}{l}\text { Decoction } \\
\text { Direct }\end{array}$ & Internally ,oral & $\begin{array}{l}\text { Used for repair of bone } \\
\text { Diabetes mellitus }\end{array}$ & 6.50 \\
\hline $\begin{array}{l}\text { Khal Tehsil } \\
\text { Rabat }\end{array}$ & $\begin{array}{l}\text { Rhizome } \\
\text { Fruits }\end{array}$ & $\begin{array}{l}\text { Decoction } \\
\text { Direct }\end{array}$ & Oral & $\begin{array}{l}\text { For diarrhea, and for cancers } \\
\text { Diabetes mellitus }\end{array}$ & 3.75 \\
\hline
\end{tabular}


According to the result of our study, most of the informants usede $B$. lycium for the management of diabetes mellitus, followed by bone repair $10 \%$, diarrhea $5 \%$, and liver issues serum glutamic pyruvic transaminase (SGPT) (7.5\%) (Figure 4).

Previously it was well established that $B$. lycium is highly medicinal plant. In recent study, the crude methanol extract of $B$. lycium has anxiolytic, central nervous system depressant, and analgesic activities (Samiullah et al. 2020). According to Katare et al. (2020), the alkaloid berberin in the B. lycium is a potential candidate for COVID-19. In another study, different parts of the plant are used for bone fracture, and also used as carminative, diuretic, antiseptic (ljaz et al. 2020). In the study conducted by Hu et al. (2020) methanolic extract of B. lycium shown excellent cytotoxic, brine shrimp lethality, and antioxidant activities. The plant is also have indicating the potential of this plant against colorectal and breast cancer. The methanolic extract of $B$. lycium is mentioned in the study by Yousaf et al. (2018) show antiviral activity against Hepatitis C Virus. According to the ethnopharmacological study conducted by Ahmad et al. (2015), the rhizome of $B$. lycium is used for the treatment of hypertension.
Besides the rhizome of $B$. lycium, fruits is also medicinally important to be hypoglycemic, antiinflammatory, anti-carcenogenic, and antipyretic especially in diabetic patients. It may also be beneficial in iron deficiency (Madiseh et al. 2014; Sood et al. 2010). Sher (2011) reported that the plant is used for cut and wound healing. According to Khan et al. (2010), dried powdered bark of B. lycium is used for internal wounds, dysentery, and throat pain.

\section{Methodology of herbal formulation and administration}

About $65 \%$ of ethnomedicine were administrated orally, while $35 \%$ used as external ways. In the survey, local informants described three different methods for drug preparation to treat various kinds of human ailments. The most common was decoction followed by powder, eating, and poultice (Figure 5). Most of the respondents, dried rhizome $(500 \mathrm{mg})$ is boiled in 4 cups $(100 \mathrm{~mL})$ of water for 15 minutes, the liquid is filtered with a piece of cloth and stored in a glass bottle in clean bottle. This decoction is given to patients suffering from diarrhea, stomachache, jaundice, etc.

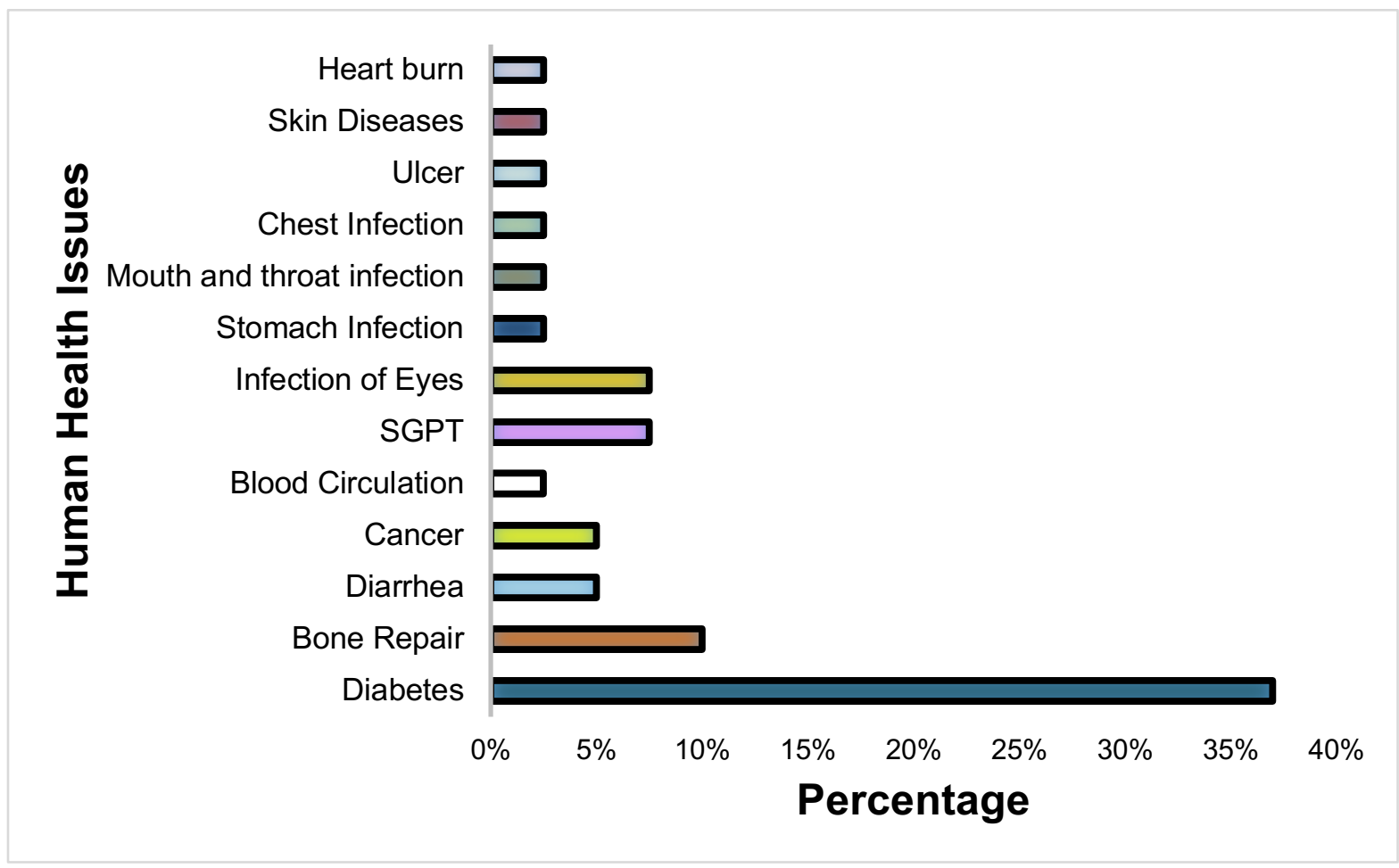

Figure 4. Different parts of $B$. lycium used to treat various human ailments. 


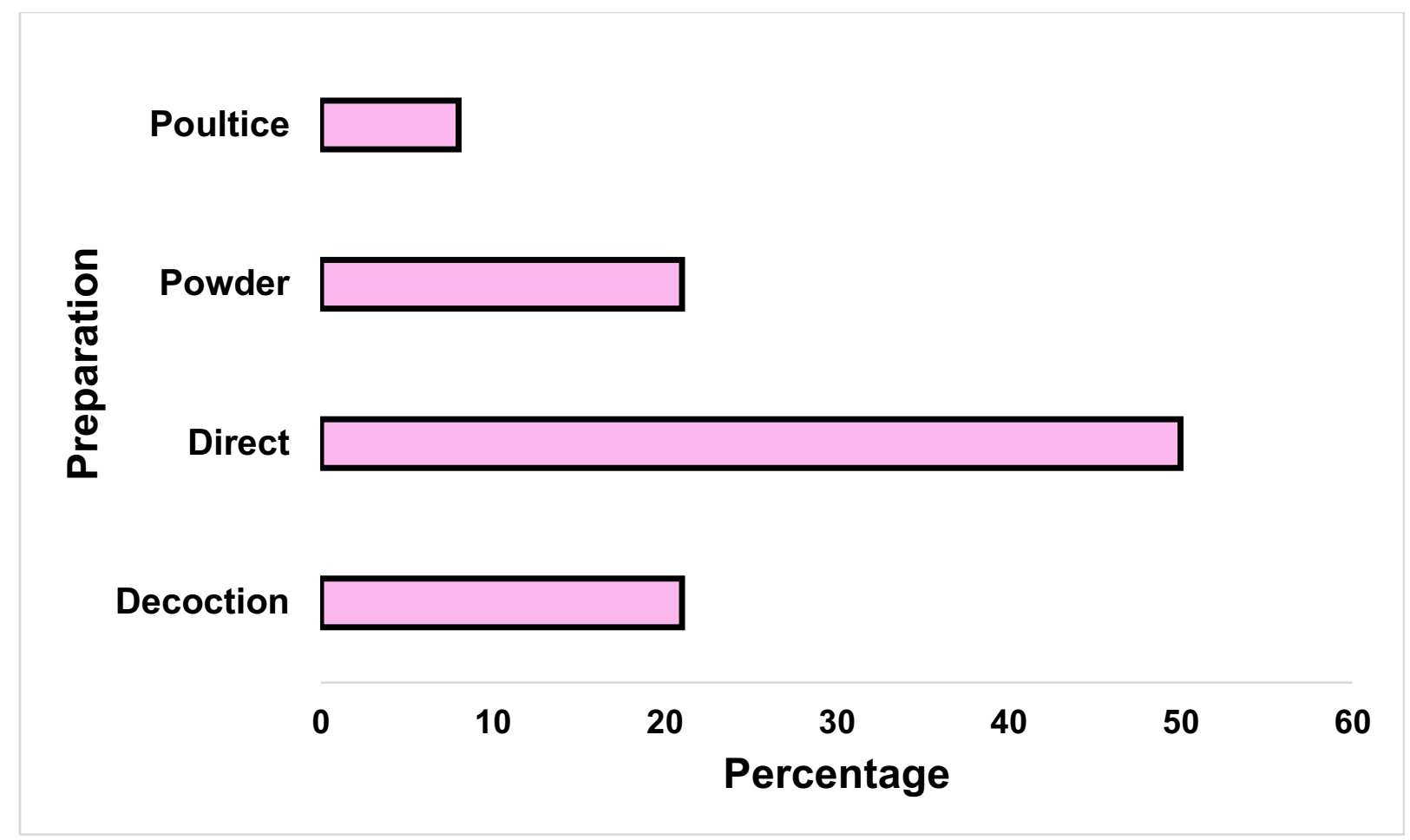

Figure 5. Different Dosage-forms of $B$. lycium Royle used in the management of various human ailments.

\section{Local market values}

Local herbal markets are cultural places for the native people where a variety of herbal drugs are marketed and traded. Furthermore, these herbal markets also represent the botanical diversity of a specific area (de Albuquerque et al. 2007). The derived income from the sale of $B$. lycium plants is very important for lower-income households to fulfill their basic needs because the people of Lower Dir have a monthly personal cash income of 12,000 to 16,000 rupees or lower, and the area is mostly undeveloped (Ahmad et al. 2017). Native people of district Lower Dir collect rhizome and fruit of $B$. lycium and sell it in local markets, thus earning their income (Figure 6). The economic values for $B$. lycium available in local markets were determined in the Pakistani currency and converted to US dollars.

\section{Berberis lycium status in the study area}

During ethnobotanical interviews, it was observed that $40 \%$ of informants were directly involved in the collection B. Iycium. Of these, $20 \%$ of respondents collected rhizomes at $10 \mathrm{~kg}$ per capita per month, $35 \%$ at $3 \mathrm{~kg}$ per capita per month, $45 \%$ at $2 \mathrm{~kg}$ per capita per month. Moreover, 25 respondents were also found to collect fruits of Berberis for market value as well as for medicinal purposes. According to the questionnaire results, $30 \%$ of the respondents used $B$. Iycium as ethnomedicine due to ease of availability for suggested human ailments, $20 \%$ low price, $17 \%$ absences of basic health facilities, and $15 \%$ suggestion from the elder's people of the family.

\section{Status of traditional practitioners}

In Pakistan, there are about 130000 homeopaths, 455 Vaids and 3584 Hakems (traditional practitioners) registered. Nearly 457 Tibbi-e-Unani clinics and dispensaries are providing human healthcare facilities. Approximately 300-350 herbal medicines producing industries, and 300 homeopathic drug-producing companies are present (Hussain et al. 2009). In the present explorative study, we interviewed 61 respondents, of these, 18 were Hakems and 12 were Panseries (herbal product sellers). According to our ethnobotanical interviews, questionnaires, and inquires, 15 Hakems informed us that they gained the traditional knowledge about $B$. lycium from their family elder, while 12 of them were involved in the collection of $B$. lycium for economic reasons, and 3 were including the fruits in their diet for nutritional purposes.

\section{Conservation status}

Over-exploitation for phytochemical and economic purposes threatens the richness of the medicinal flora in Pakistan. The increase in the human population is straining these resources (Malik et al. 2005). In Pakistan Berberis has important ecocommercial, cultural, traditional and livelihood roles in hilly regions (Khan et al. 2016). Overharvesting of $B$. lycium is largely caused through population pressure and associated factors: an increase in demand for cultivation land, the population of livestock, and forest utilization to meet increasing demands for fodder, timber, and fuelwood, as well as 
the local demand for market and medicinal value. Lower Dir is harboring a large number of Afghan refugees who are completely dependent on herbal medicine for their health issues. "Twenty years ago $B$. lycium was very abundant in the district. The local people collected it when they needed it at home for the treatment of human health issues and at that time there was no market value" (Personal Communication with Local elder). Now B. Iycium has completely vanished from most regions in the district.

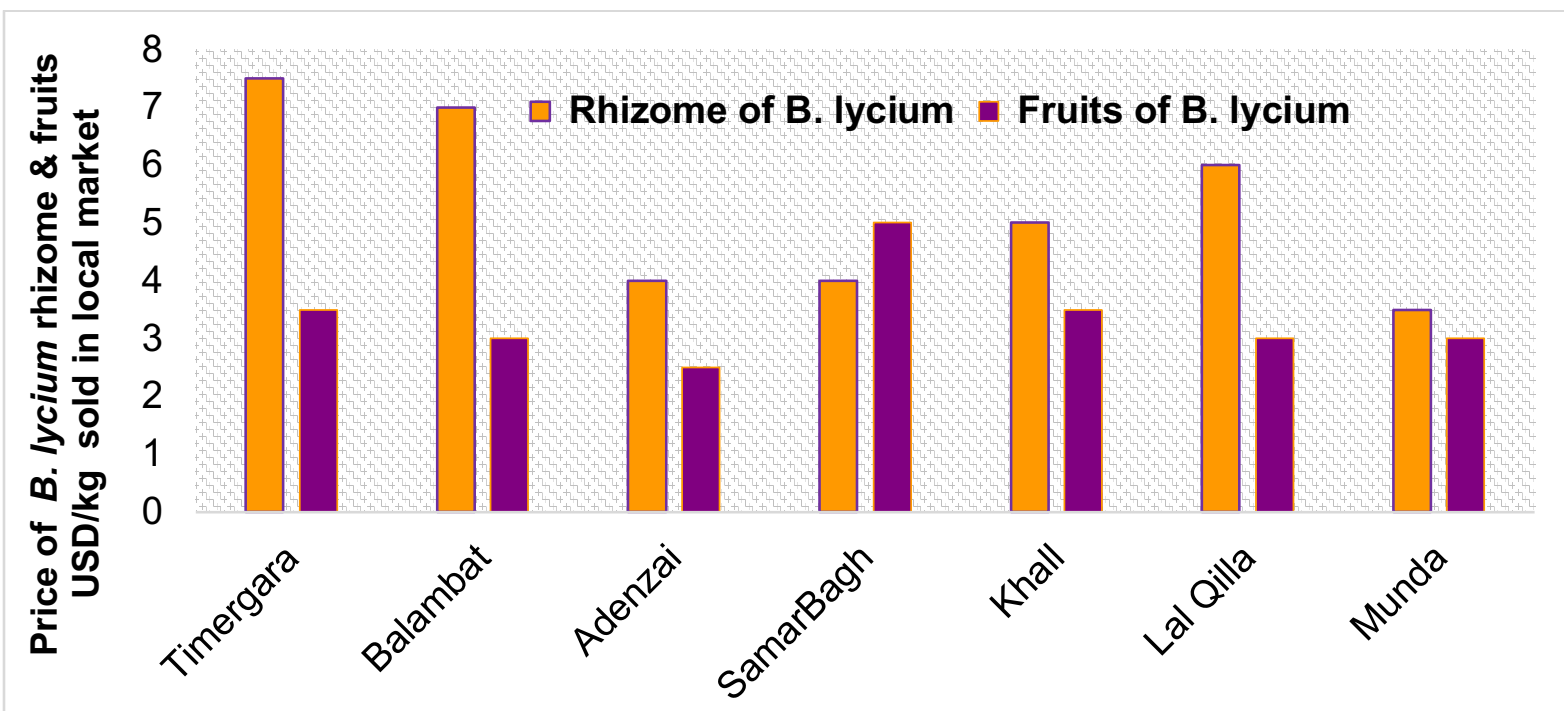

Study Sites

Figure 6. Prices of rhizomes and fruits of Berberis lycium sold in Lower Dir local markets

According to the well-established medicinal and market importance, this species urgently needs to be conserved for future generations. The species needs an ex-situ conservation program at the botanical garden, nurseries, and farms. In in-situ conservation, the plants are protected in their native habitats; this type of conservation is aimed at keeping intact the ecological relationships between species and, in some cases, the cultural relationship between people and wild species. This kind of strategy may involve a formal protected area recognized by governments, such as sacred groves, springs and mountains and reserves for medicinal plants where communities have decided that no other extractive activities are allowed (Shabbir and Jabeen, 2012). Furthermore, widespread informal conservation such as leaving plants to reproduce, not treading on their habitat and sustainable management practices would provide a benefit. Co-ops that spread seeds or plants sharing or designating habitats such as parks and other public areas could benefit the species population and awareness by locals also. This leads to ideas for future, applied research on the feasibility of establishing a formal conservation strategy.

\section{Conclusions and future perspective}

The following conclusions are obtained in light of the present study. The present research was carried out to study the different features of $B$. lycium plants, where $37.5 \%$ of people used it for diabetes mellitus, for bone repair $10 \%$, diarrhea $5 \%$, cancer $5 \%$, clearing of blood $2.5 \%$, SGPT $7.5 \%$, eye infection $7.5 \%$, stomach infection $2.5 \%$, chest infection $2.5 \%$, ulcer $2.5 \%$, heartburn $2.5 \%$, skin disease $2.5 \%$, and for mouth and throat infection $12.5 \%$. According to $25 \%$ of interviewed people, B. lycium survives mostly in inaccessible areas. According to the opinion of $30 \%$ of people, the plant is facing threat due to deforestation, road, and building construction. The older participants (over 60 years of age) had more information about the plant. In this traditional knowledge of the local respondents can be used as an effort to promote the conservation of $B$. lycium in the district Dir Lower. The current ethnobotanical survey concludes that the populations of Dir Lower have enough information regarding the medicinal and economic benefits of this important medicinal plant, but this knowledge is often not transferred to the younger generation. Given this, we suggest to the local and district forestry department, governmental organizations, and non-governmental 
organizations to encourage, motivate, and also create awareness among the native people, herbalists, harvesters, farmers, elder people, herders, hakeems, pastoralists, pansaries, transporters, and market vendors who use this ethnomedicine to prevent and conserve the naturally potent medicinal plants from overexploitation.

\section{Declarations}

Ethics statement: All participants provided prior informed consent before any interviews were conducted.

Conflict of interests: The authors declare that they have no competing interests.

Consent for publication: Not applicable - no personal data are included in this manuscript.

Funding: This research did not receive any funding. Authors' contributions: Authors' contributions in this article are; LA, FU, and IK collected the plant species. LA prepared the first draft of the manuscript. FU and IA carried out the field survey. LA conceived and designed the research and identified the collected sample. AJS, WR, HAJ and RB gave counsel and revised the manuscript. All authors read and approved the final manuscript.

\section{Acknowledgments}

The authors thankfully acknowledge the Department of Botany, Shaheed Benazir Bhutto University, Sheringal, Dir Upper to carry out this research project and also thankful to the native residents of the study area for providing relevant ethnomedicinal information.

\section{Literature cited}

Abbasi AM, Khan MA, Ahmad M, Zafar M. 2011. Medicinal plant biodiversity of lesser HimalayasPakistan. Springer Science \& Business Media; Springer New York Dordrecht Heidelberg London. doi:10.1007/978-1-4614-1575-6

Ahmad I, Aqil F, Owais M. 2006. Modern Phytomedicine: Turning Medicinal Plants into Drugs. John Wiley and Sons Ltd., New York.

Ahmad L, Semotiuk A, Zafar M, Ahmad M, Sultana S, Liu QR, Zada MP, Abidin SZ, Yaseen G. 2015. Ethnopharmacological documentation of medicinal plants used for hypertension among the local communities of DIR Lower, Pakistan. Journal of Ethnopharmacology 175:138-146.

Ahmad L, Semotiuk AJ, Zafar M, Ahmad M, Liu QR, Khan I, Mazari P. 2017. Plant Foundations of the Home: Key plant species provide food, income, and Economic Development potential to Indigenous Pakistani families of Dir Lower, Pakistan. Bulletin of Environmental Pharmacology and Life Sciences 6(7): 6-32.
Ali SI. 2008. Significance of flora with special reference to Pakistan. Pakistan Journal of Botany 40:967-71.

Anamaya P, Hasanuzzaman SM. 2006. Guide on Medicinal and aromatic plants of SAARC countries, SAARC Agricultural Information Center CSAIC, First edition, Publishers, New Delhi 103-105.

Baydoun SL, Chalak H, Dalleh, Arnold N. 2015. Ethnopharmacological survey of medicinal plants used in traditional medicine by the communities of Mount Hermon, Lebanon. Journal of Ethnopharmacology 173:139-56.

Bhatti, G.R., R. Qureshi and M. Shah. 1998. Ethnobotany of Calotopis procera with special reference to the people of Nara Desert. Scientific Sindh Annual Research Journal 5:13-22.

Chaachouay N, Benkhnigue O, Fadli M, El Ayadi R, Zidane L. 2019. Ethnobotanical study of medicinal plants used to treat osteoarticular diseases in the Moroccan Rif, Morocco. Journal of Pharmacy Pharmacognocy Research 7(6):454-470.

Cotton CM, 1996. Ethnobotany: Principles and Applications Chichester. John Wiley and Sons Ltd., New York.

De Albuquerque UP, Monteiro JM, Ramos MA, de Amorim ELC. 2007. Medicinal and magic plants from a public market in northeastern Brazil. Journal of Ethnopharmacology 11 (1):76-91.

Flora of Pakistan.1989. http://www.tropicos.org/Name/40001957?Projectid= 32

Goodman SM, Ghafoor A. 1995. The Ethnobotany of Southern Baluchistan, Pakistan, with particular reference to medicinal plants. Fieldiana Botany 31(IV):1-84.

Hamayun M, Khan SA, Iqbal I, Rehman G, Hayat T, Khan MA. 2005. Ethnobotanical profile of Utror and Gabral valleys, district Swat, Pakistan. Ethnobotany Leaflets 1:9.

Hamayun M. 2003. Ethnobotanical studies of some useful shrubs and trees of District Buner, NWFP, and Pakistan. Ethnobotany Leaflets 1:12.

Heywood V. 2011. Ethnopharmacology, food production, nutrition and biodiversity conservation: towards a sustainable future for indigenous peoples. Journal of Ethnopharmacology 137:1-15.

Hu X, Islam S, Ameen F, Alarfaj AA, Murtaza G, Mannan A. 2020. In vitro Screening of Berberis lycium Root Extract on HCT-116 and MCF-7 Cell Lines. Indian Journal of Pharmaceutical Sciences 31:53-7.

Hussain J, Khan AL, Rehman N, Hamayun M, Shah T, Nisar M, Lee I. 2009. Proximate and nutrient analysis of selected vegetable species: a case study 
of Karak region, Pakistan. African Journal of Biotechnology 8(12):2725-2729.

ljaz S, Perveen A, Ashraf S, Bibi A, Dogan Y. 2020. Indigenous wild plants and fungi traditionally used in folk medicine and functional food in District Neelum Azad Kashmir. Environment, Development and Sustainability 1:1-24.

Irshad AH, Pervaiz AH, Abrar YB, Fahelboum I, Awen BZ. 2013. Antibacterial activity of Berberis lycium root extract. Trakia Journal of Sciences 11(1):89.

Jan HA, Wali S, Ahmad L, Jan S, Ahmad, N, Ullah N. 2017. Ethnomedicinal survey of medicinal plants of Chinglai valley, Buner district, Pakistan. European Journal of Integrative Medicine 13:64-74.

Katare AK, Singh B, Shukla P, Gupta S, Singh B, Yalamanchili K, Kulshrestha N, Bhanwaria R, Sharma AK, Sharma S, Sneha. 2020. Rapid determination and optimisation of berberine from Himalayan Berberis lycium by soxhlet apparatus using CCD-RSM and its quality control as a potential candidate for COVID-19. Natural Product Research 12:1-6.

Kew. How many flowering plants are there in the world? 2015. Available via http://www.kew.org/ science-conservation/plants-

fungi/environment/how-many-flowering-plants-arethere-world.

Khan H, A. Rauf. 2014. Medicinal plants: economic perspective and recent developments, World Applied Science Journal 31 (11), 1925-1929.

Khan M, Giessrgl B, Vonach C, Madlener S, Prinz S, Herbaceck I, Hölzl C, Bauer S, Viola K, Mikulits W, Quereshi RA, Knasmüller S, Grusch M, Kopp B, Krupitza G. 2010. Berberine and a Berberis lycium extract inactivate Cdc25A and induce a tubulin acetylation that correlate with HL-60 cell cycle inhibition and apoptosis. Mutation Research 683:123-130.

Khan M, Giessrgl B, Vonach C, Madlener S, Prinz S, Herbaceck I, Hölzl C, Bauer S, Viola K, Mikulits W, Quereshi RA, Knasmüller S, Grusch M, Kopp B, Krupitza G (2010). Berberine and a Berberis lycium extract inactivate Cdc25A and induce a tubulin acetylation that correlate with HL-60 cell cycle inhibition and apoptosis. Mutation Research 683:123-130.

Khan T, Khan IA, Rehman A, Ahmed N. 2016. Conservation status evaluation of Berberis species across the Karakoram Mountain Ranges, Pakistan using IUCN red list categories and criteria. Journal of Forestry Research 27 (6):1385-1390.

Kloucek P, Polesny Z, Svobodova B, Vlkova E, Kokoska L. 2005. Antibacterial screening of some Peruvian medicinal plants used in Calleria District. Journal of Ethnopharmacology 99:309-312.
Madiseh MR, Heidarian E, Rafieian-Kopaei M. 2014. Biochemical components of Berberis lycium fruit and its effects on lipid profile in diabetic rats. Journal of HerbMed Pharmacology 3(1):15-19.

Malik F, Hussain S, Dil AS, Hannan A, Gilani AH. 2005. Islamic Republic of Pakistan. "Eds. Ong, CK, G. Bodeker, C. Grundy, G. Burford and K. Shein. WHO Global Atlas of Traditional, Complementary and Alternative Medicine (Map Volume). World Health Organization, Geneva 165-169.

Martin GJ. 1995. Ethnobotany: A Method and Manual. Champan and Hall, London.

Newman DJ, Cragg GM. 2007. Natural products as sources of new drugs over the last 25years. Journal of Natural Products, 70:461-477.

Qureshi RA, Ghufran MA. 2005. Medicinal value of some important roses and allied species of Northern Area of Pakistan. In: Pakistan Rose Annual. (Ed.): M. Hashmi. Pictorial Printers (Pvt.). Ltd. Islamabad, 2429 pp.

Rashid A, Arshad M. 2002. Medicinal plant diversity, threat imposition and interaction of a mountain people community. In Proceeding of Workshop on Curriculum Development in Applied Ethnobotany. Published by the Ethnobotany Project, WWF Pakistan, 34-D/2, Sahibzada Abdul Qayuum Road Peshawar, Pakistan, pp. 84-90

Rates SMK. 2001. Plants as source of drugs. Toxicon 39:603-613.

Samiullah, Iqbal J, Khan A, Muhammad S, Jan SU, Gul R. 2020. Analgesic and neuropharmacological activities of Berberis lycium Royle collected from district Sherani Balochistan, Pakistan. Pakistan Journal of Pharmaceutical Sciences 33(4):16891695.

Schippmann U, Leaman DJ, Cunningham AB.2002. Impact of cultivation and gathering of medicinal plants on biodiversity: global trends and issues. Biodiversity and the ecosystem approach in agriculture, forestry and fisheries. FAO, Rome

Shabbir R, Jabeen A. 2012. Contribution to the red list of plants of Pakistan: A Review. Journal of Biodiversity \& Envronmental Sciences 2(8):14-25.

Shaheen S, Ramzan S, Khan F, Ahmad M. 2019. Adulteration in Herbal Drugs: A Burning Issue. Springer Nature Switzerland AG. Part of Springer Nature.

Sher H. 2011. Ethnoecological evaluation of some medicinal and aromatic plants of Kot Malakand Agency, Pakistan. Scientific Research and Essays 6(10):2164-2173.

Sood P, Modgil R, Sood M. 2010. Physico-chemical and nutritional evaluation of indigenous wild fruit Kasmal, Berberis lycium Royle. Indean Journal of Natural Products and Resources 3(1):362-366. 
Yousaf T, Rafique S, Wahid F, Rehman S, Nazir A, Rafique J, Aslam K, Shabir G, Shah SM. 2018. Phytochemical profiling and antiviral activity of Ajuga bracteosa, Ajuga parviflora, Berberis lycium and Citrus lemon against Hepatitis C Virus. Microbial pathogenesis 1(118):154-158. 